体力科学 (2003) 52, 99 110

\title{
異なる種類のペプチドおよびコラーゲンの腸管壁通過現象
}

\author{
鈴川- 宏 ${ }^{1)}$ 谷 浩 充 $^{21}$ 小山内 弘 和 ${ }^{3)}$ \\ 白土男女幸3) 中野 昭 一1)
}

\section{PENETRATION OF DIFFERENT KINDS OF PEPTIDES OR COLLAGEN THROUGH THE INTESTINAL MEMBRANE}

\author{
Kazuhiro Suzukawa, Hiromitsu Tani, Hirokazu Osanai, \\ Minayuki Shirato and Shoichi NaKano
}

\begin{abstract}
Penetration of different kinds of peptides or collagen peptide through the intestinal membrane was studied in two experiments using an in vitro rat everted intestine penetration model. In Study 1. twelve 11-wk-old rats (Wistar strain) were randomly divided into two groups and penetration of whey peptide $(n=6)$ and soy peptide $(n=6)$ through the intestinal membrane was compared. In Study 2, fourteen 11-wk-old rats (Wistar strain) were divided into a control group $(\mathrm{n}=7)$ and a training group (treadmill running at a speed of $20-35 \mathrm{~m} / \mathrm{min}$ for $15 \mathrm{~min} / \mathrm{day}, 5$ days/wk for $4 \mathrm{wk}$; $\mathrm{n}=7$ ), and penetration of collagen peptide through the intestinal membrane was investigated in the two groups. In Study 1, the quantity of whey peptide that penetrated through the intestinal membrane was significantly greater than that of soy peptide $(P<0.01)$. In Study 2, body weight was significantly lower in the training group than in the control group except during 12 and $12.5 \mathrm{wk}$ of age (13.5 wk; $\mathrm{P}<0.01$, others : $\mathrm{P}<0.05)$. The weights of heart, kidney, and spleen were significantly increased, and the weight of fat was significantly decreased in the training group compared to the control group $(\mathrm{P}<0.05, \mathrm{P}<0.05, \mathrm{P}<0.01, \mathrm{P}<0.05$, respectively $)$. In both groups, a portion of collagen peptide penetrated through the intestinal membrane; but there was no significant difference in quantity between the two groups. In conclusion, the inhibition of weight gain in the training group was possibly caused by decreased feeding from lack of appetite with enforced exercise. These find. ings suggest that whey peptide penetrated through the intestinal membrane in greater quantities than soy peptide, and collagen peptide is not affected by enforced exercise.
\end{abstract}

(Jpn. J. Phys. Fitness Sports Med. 2003, $52: 99 \sim 110$ )

key word : rat, whey peptide, soy peptide, collagen peptide, intestinal membrane

\section{I. 緒}

一般に，体内に取り入れられた栄養素は，消化 管内で管腔内消化，さらに腸管粘膜壁に扮ける膜 消化を受けて, その最小構成単位に分解されて吸 収される，従来，食品中の蛋白質，あるいはある 程度の分子量を有する蛋白体が，そのままの形で
腸管粘膜壁を通過し体内に取り入れられた場合, 異種蛋白質の抗原として作用し, 体内で抗原抗体 反応を起こさせ，アレルギー，アナフィラキシー の要因となり危険であると考えられていだ．し かし, 近年, 腸粘膜の吸収機序としては受動輸送, 能動輸送, 促進拡散の他に, 成人においても飲作 用やパーメーションなどの機構が明らかにされて
1)日本体育大学:

干158-8508 東京都世:田谷区深沢7-1-1

2) 東邦高等学校

干465-8516 愛知県名古屋市名東区平和が丘3-11

3) 日本体育大学大学院体育科学研究科 健康科学. スポーツ医科学系

干158-8508 東京都世田谷区深沢7-1-1
Nippon Sport Science University 7-1-1, Fukasawa,

Setagaya-ku, Tokyo, 158-8508. Japan

Toho Senior High School 3-11. Heiwagaoka, Meitou, Nagoya,

Aichi, 465-8516

Graduate School of Health and Sport Science, Nippon Sport

Science University 7-1-1, Fukasawa, Setagaya-ku, Tokyo,

158-8508, Japan 
きており,ことに体内で生理機能を発揮する機能 性蛋白体については，必ずしも最小構成単位にま で分解されなくても吸収される可能性のあること が明らかにされてきている2).したがって，どの 程度の蛋白体がその働きを維持したまま腸管壁を 通過し得るかについては問題となるところであろ j.

スポーツ選手の多くは，競技力向上を目的とし て筋力トレーニングを行っている，高強度の筋力 トレーニングは筋肥大を起こさせ, 最大筋力を必 要とする運動パフォーマンスの向上に寄与してい る。また，筋力トレーニングによる筋肥大のため には，筋蛋白の合成が必要である。そのため，筋 蛋白の増加を目的とした多くの蛋白性食品が開発 されてきており，スポーツ選手達の多くは通常食 の他, 種々のサプリメントを捸取している。この ように，スポーツ現場では蛋白質の摂取量増大 により競技成績の向上を期待する面が見受けら れ3), 最近ではホエイペプチドおよび大豆ぺプチ ドが利用されているようである，事実，先行研究 ではホエイペプチドおよび大豆ペプチドの投与 が，ともにヒトでの運動能力を向上させたとして いる ${ }^{4 \sim 6)}$ 。また，両ぺプチドを比較した場合に はホエイペプチドの方が栄養価は高く，一方，大 豆ペプチドは血清コレステロール值を低下させる 働きがあり ${ }^{7)}$, 減量効果を期待するようなスポー ツ選手で利用価值が高いとされている ${ }^{5,8)}$ 。しか し，経口で搨取した蛋白質も体内に吸収されなけ ればその価値はなく，実際に腸管壁を通過しどの 程度の量が吸収されるかについては明らかにされ ていない.

一方, 近年, 生体内の至る所に存在する蛋白質 としてのコラーゲンペプチドの䝮取が注目されて きている。コラーゲンはアミノ酸スコアからみた 栄養価は低いものの, 細胞外マトリックスとして 最も重要な繊維成分を構成し ${ }^{9)}$, 靶帯や腱などに 多く存在する，事実，スポーツ現場ではこれらを 補給する意味からもコラーゲンペプチドを含むサ プリメントなどがよく利用されている。高強度運 動やコンタクトスポーツでは, 腱や勒帯に負荷が 加わり損傷も起こしやすく, 組織修復のためには
組織におけるアミノ酸の絶対必要量が増すと考え られる。したがって，これらの損傷の修復のため に，経口摂取したコラーゲンペプチドが腸管壁を 通過することは好ましいと予想される。

そこで本実験では，実験 1 としてスポーツ選手 達にサプリメントとしてよく利用されているぺプ チドの吸収を評価するために，ホエイペプチドと 大豆ペプチドのラットにおける腸管壁通過現象の 相異について検討を行った。また，実験 2 として 強制運動を行わせたラットにおけるコラーゲンペ プチドの腸管壁通過現象を測定し，強制運動によ る影響がみられるか否かの実験を試みた。

\section{II. 方法}

\section{A . 実験装置}

本実験で使用した腸管壁通過現象を測定するた めに用いたラットの翻転腸管の作成方法と，腸管 潅流装置の概要を図 1，2 に示した。まず，ラッ トをネンブタール麻酔下で開腹し，空腸下部から 回腸上部にかけて小腸のみを摘出し，図 1 にみら れるように㼑転した。その後，直ちにその腸管を 空腸側から $12 \mathrm{~cm}$ の長さに切断し, 図 2 に示す $\mathrm{A}$ の位置に接続した。次に，この潅流装置の上部 (漿膜側)と下部(粘膜側)とに, 同じ Tyrode 液を

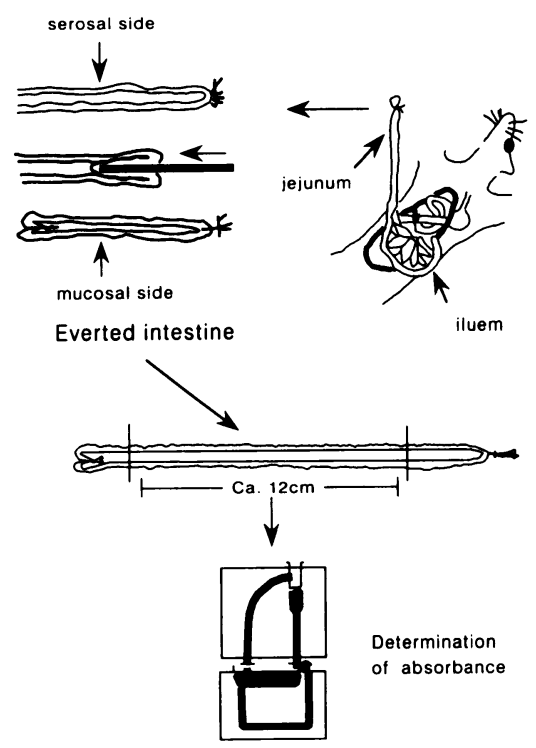

Fig. 1. Experimental method of everted intestine. 


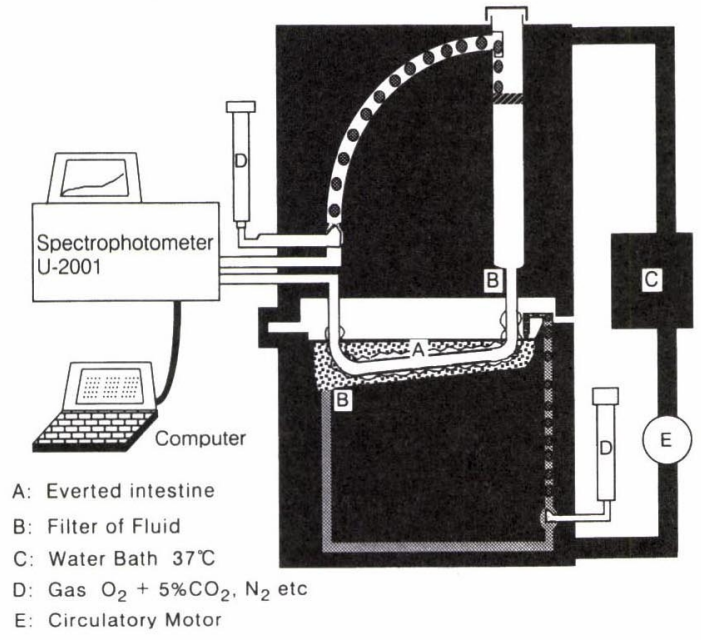

Fig. 2. The application of a new apparatus to the circulation of the penetrated fluid through the in testinal membrane.

等量注入し， $5 \% \mathrm{CO}_{2}$ を加えた $\mathrm{O}_{2}$ によりbubble lift circulation を行い, 漿膜側液の潅流経路 内に置いた分光光度計 (U-2100型ダブルビーム分 光光度計：日立社製)により紫外部吸光の変動を 継時的に測定した。この潅流装置を使用した粘膜 側に加えた紫外部吸光物質の漿膜側への移動の測

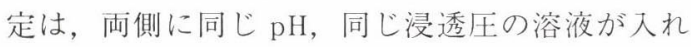
られているものの, 漿膜側から粘膜側に約 $17 \mathrm{~cm}$ の水圧が掛かっており, 少なくとも $\mathrm{pH}$, 浸透压 および水圧による受動輸送に抗しての通過，军 なわち, 能動輸送として測定することが可能であ る ${ }^{10)}$ 。なお, 得られたデー夕は, Microsoft Windows 98 を搭載したComputer(松下電器産業社 製)に分析計データー受信ソフト「とったる君」(日 製ソフトウェア社)を用いて取り込み，腸管壁通 過現象で得られた吸光度の増加面積については自 動解析ソフト(日製ソフトウェア社)により算出し た。

\section{B. 実験 1}

\section{B - 1 . 実験動物}

本実験では10週齢の Wistar 系雄性ラット(日 本クレア社)を用い, 1 週間の経過観察の後, 11 週齢にて実験に供した。なお，飼育期間中の水お
よび飼料 ( F-2 ; 船橋農場)については自由摂取と した。

\section{B - 2. 燔転腸管の作成}

既に報告した手法 ${ }^{10)} に よ り ， 11$ 週齢のラット をネンブタール麻酔下で開腹し, 空腸から回腸上 部を約 $16 \mathrm{~cm}$ 摘出した. 次いで, 摘出した腸管 を Tyrode 液で洗浄後, 粘膜側に触れないよう留 意しながら腸管を眽転し, 約 $12 \mathrm{~cm}$ の長さで切 断して直ちに眽転腸管を前述した潅流装置に接続 した(図 1，2）。なお，両側の接続した部分約 1 $\mathrm{cm}$ を除き，奏際にTyrode溶液中に浸す腸管部分 の有効腸を約 $10 \mathrm{~cm}$ とするように調節した.

\section{B-3. 試 料}

本実験では，ホエイペプチド(ALATAL817； 日本プロテン社製， $\mathrm{n}=6$ ) と大豆ペプチド(ハイ ニュート DH；不二製油社製， $\mathrm{n}=6$ ）を用いた。 ホエイペプチドは, 牛乳からカゼインと脂肪を除 いたホエイ蛋白を酵素処理することによって製造 された加水分解物であり, 平均分子量は約 1,100 ダルトンである。また，大豆ペプチドは大豆蛋白 を酵素分解し，オリゴペプチドまで低分子化した 平均分子量が約 10,000 ダルトンのものである.

\section{B - 4 。実験手順}

あらかじめホエイペプチドと大豆ペプチドの腸 管壁通過現象を測定するに際して，両者の紫外部 吸光度から波長曲線を測定した。その成績から， $278 \mathrm{~nm}$ に特異的な吸光度を有していることを確 認し，既に報告 ${ }^{10)} し た 278 \mathrm{~nm}$ の波長で経時的測 定を行い腸管壁通過現象を測定した。なお，実際 の腸管壁通過現象の測定は, 前述した潅流装置を 用いて行い, 紫外部吸光度の経時的変化により求 められた吸光度増加面積により評価した。図 3 に潅流装置を用いて求められた吸光度増加面積 の1例在示した。すなわち, ラットの譒転した腸 管を潅流装置に接続した時点を０分として30分間 Tyrode 液を潅流した後に, 実験 1 では粘膜側に ホエイペプチドあるいは大豆ペプチドを添加し， さらに30分間の潅流を行った(計60分間)。図にみ られるように, 粘膜側へ物質を添加する前の30分 間の漿膜側の曲線，これは残留血液中血漿蛋白お よび可溶性組織蛋白の一部と思われるが, この曲 


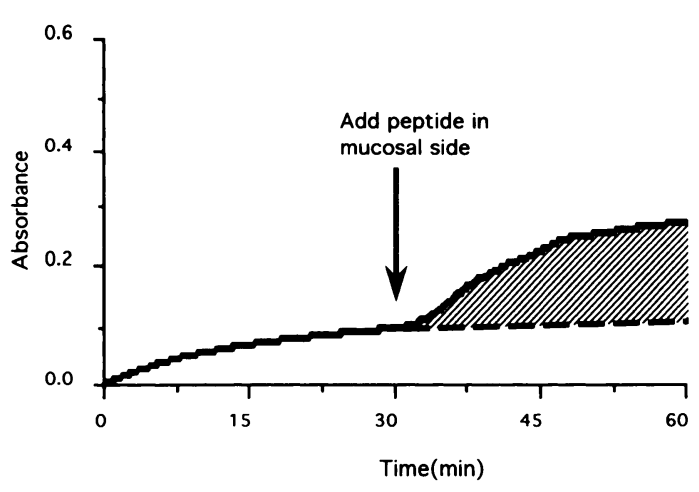

Fig. 3. Penetration through intestinal mambrane of peptide.

線を基礎曲線として, 粘膜側へ物質添加後の槳膜 側の曲線の変化と, 前述の基礎曲線との差によっ て生じる面積を測定し, 吸光度増加面積として評 価した(図中斜線部)。なお，この時の粘膜側液の ホエイペプチドあるいは大豆ペプチド濃度は $1.0 \%$ 濃度に調整した。

次に, 60分間の潅流終了直後に漿膜側液の全量 を採取し， - $80^{\circ} \mathrm{C} に$ 設定したディープフリーザー 内にて凍結保存した。そして, 全実験が終了した 時点で全検体を加水分解した後にアミノ酸分析を 行った。なお，アミノ酸分析には高速アミノ酸分 析計 L-8500 (日立製作所製)を用い, HPLC 法に て行った。

\section{C. 実験 2}

\section{C - 1. 実験動物}

本実験では10週齢の Wistar 系雄性ラット（日 本クレア社)を用い, 動物飼育室で 1 週間の経過 観察の後，11週齢から 2 群に分け，15週龄までの 4 週間, 以下に示す条件飼育を行った。すなわち, 1）トレッドミル走行を週5日間行わせた群 (Training群；n=7)，2）通常飼育を行う対照群 (Control群；n=7)の 2 群である.また, 両群と もに飼育期間を通して水および飼料 $(\mathrm{F}-2$; 船橋 農場) は自由搷取とし, ラットの体重および飭の 撕取量を週に2 回測定した.なお,ラットは 1 ケー ジにつき 2 〜 匹で飼育した。したがって，各群 の飭の摂取量は，1ケージにつき 1 ケ所備え付け
てある飭の摂取量を計測し，各々ケージ毎に 1 匹 あたりの平均値として求めた。

\section{C - 2。強制運動}

強制運動を行わせる Training 群には, 小動物 用トレッドミル(鈴屋製作所製)を用い，1日に 1 回，週 5 日間のトレッドミル走行を 4 週間行わせ た。また，トレッドミル走行に際しては電気刺激 などを用いず，走行を著しく拒否した場合には尾 上方を手で軽く叨く，あるいは手で押して走行を 促した。運動負荷については, 速度 $20 \mathrm{~m} / \mathrm{min}$ よ り開始し, 徐々に速度を増加させ速度 $35 \mathrm{~m} / \mathrm{min}$ で15分間の走行を行わせた。

\section{C - 3 . 䧽転腸管の作成}

実験開始から 4 週間後の 15 週齢に, 実験 1 と同 様にラットをネンブタール麻酔下で開腹し, 摘出 した腸管を Tyrode 液で洗浄後に㼑転し，その約 $12 \mathrm{~cm}$ の長さで切断して直ちに前述した潅流装置 に接続した(図 1，2).

\section{C-4 . 臟器重量の測定}

ラットの腸を摘出した後に脱血死させ, 臓器を 摘出した。摘出した臓器は Tyrode 液で洗浄した 後に重量を測定した。本実験で測定した臓器は, 心臓, 肝臓, 腎臓, 副腎, 脾臓および脂肪を湿重 量として測定し, 各臓器をラットの体重 $100 \mathrm{~g}$ に 対する重量として評価した。なお，脂肪について は副睪丸脂肪組織を取り出し脂肪量の指標とし た。

C - 5. 試 料

本実験では，コラーゲンペプチドとして平均分 子量が約 3,000 ダルトンのコラーゲンペプチド (Gelita-Sol. D ; ニュートリノヴァ・ジャパン株 式会社製)を用いた。

\section{C - 6. 実験手順}

本実験についても，実験 1 と同様に $278 \mathrm{~nm}$ の 紫外部吸光による腸管壁通過現象の測定を行っ た。すなわち，その測定は，翻転腸管を接続して 30分間 Tyrode 液を潅流した後, コラーゲンペプ チドを粘膜側の Tyrode 液中に添加し，さらに30 分間の潅流を行った(計60分間)。なお，この時の 粘膜側液のコラーゲンペプチド濃度は $7.5 \%$ 濃度 に調整した。 
次に，60分間の潅流が終了した直後の漿膜側液 を直ちに採取し，実験1で示した手順と同様にア ミノ酸分析を行った。

\section{D. 統計処理}

本実験で得られた各測定項目における群間の統 計学的有意差の検定は, 実験 1 の場合, 吸光度増 加面積の成績については，翻転腸管の粘膜側にホ エイペプチドと大豆ペプチドをそれぞれ添加した 場合の2群間で対応のない $\mathrm{t}$-testを行った。また, 粘膜側にホエイペプチドのみを添加した場合，大 豆ペプチドのみを粘膜側に添加した場合および粘 膜側に何も添加しなかった場合 (Control) の 3 群 間で一元配置分散分析 (One-way ANOVA) を行 い，有意差の認められた場合の多重比較には Fisher の PLSD の方法を用いた。実験 2 につい ては, Training 群と Control 群において対応のな いt-testを行った。なお，本研究における成績 の有意差については，いずれの場合も危険率 $5 \%$ 水準をもって有意とした.

\section{III. 成}

\section{績}

\section{A. 実験 1}

A-1.ホエイペプチドおよび大豆ぺプチド の吸光度増加面積

潅流装置に接続した眽転腸管の粘膜側にホエイ ペプチド，または大豆ペプチドをそれぞれ添加し てから30分間に増加した槳膜側の紫外部吸光度面 積を図 4 に示した。紫外部吸光度面積の実数值は ホエイペプチドが $6.9 \pm 0.3 \mathrm{~cm}^{2}$, 大豆ペプチド が $4.6 \pm 0.3 \mathrm{~cm}^{2}$ で，ホエイペプチドの方が大豆 ペプチドよりも有意に高值 $(\mathrm{p}<0.01)$ を示してい た。

A-2.ホエイペプチド抢よび大豆ペプチド のアミノ酸分析

困 5 に60分間の潅流が終了した直後の漿膜側液 中のアミノ酸分析の成績を示した。その結果，ホ エイペプチドを添加した場合と何も添加しなかっ た Control の比較では，すべての項目でホエイペ プチドを添加した場合の方が高值を示し，タウリ ン，アスパラギン酸およびシスチンを除き有意の

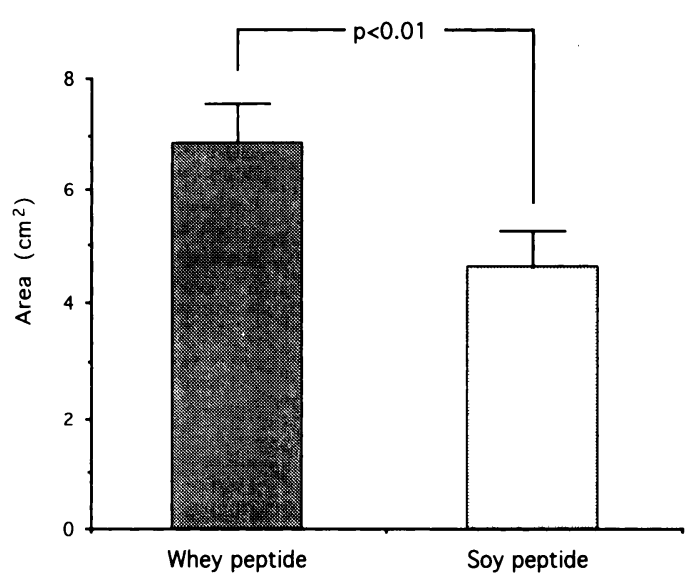

Fig. 4. Penetration of whey and soy peptide through the intestinal membrane.

Each column and vertical bar represents mean value and standard error of each group. respec. tively.

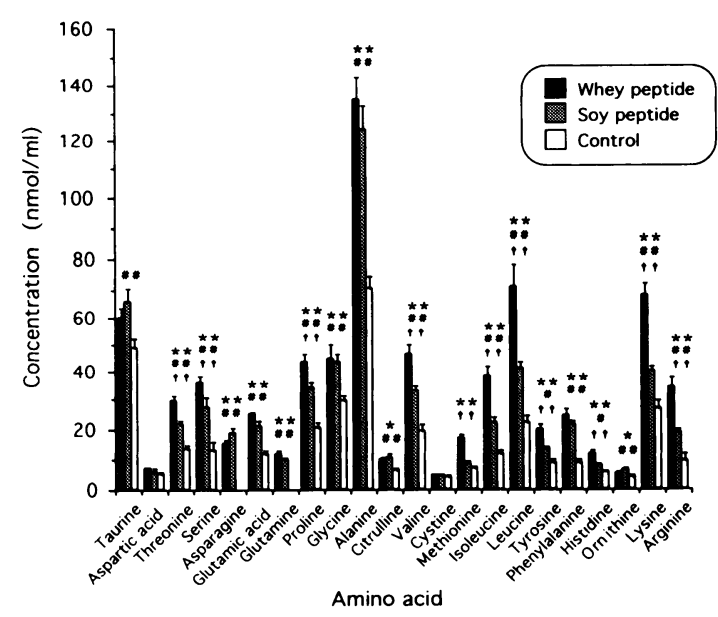

Fig. 5. Quantitative analysis of amino-acid composition of the penetrated fluid through the intestinal membrane.

Each column and vertical bar represents mean value and standard error of each group, respec tively.

* : significant difference between Whey peptide and Control, $\mathrm{p}<0.05$.

$* *$; significant difference between Whey peptide and Control, $\mathrm{p}<0.01$

\# ; significant difference between Soy peptide and Control, $\mathrm{p}<0.05$

\# \# : significant difference between Soy peptide and Control, $\mathrm{p}<0.01$

$\dagger \dagger$; significant difference between $W$ hey peptide and Soy peptide, $\mathrm{p}<0.01$. 
差が認められた(シトルリンとオルニチンは $\mathrm{p}<$ 0.05, それ以外は $\mathrm{p}<0.01$ であった). また, 大 豆ペプチドと Control を比較したところ, すべて の項目で大豆ペプチドが高值を示し，アスパラギ ン酸, シスチンおよびメチオニンを除き有意の差 が認められた(チロシンとヒスチジンは $\mathrm{p}<0.05$, それ以外は $\mathrm{p}<0.01$ であった). 次に, ホエイペ プチドと大豆ペプチドの比較では, 同程度, ある いはホエイペプチドが大豆ペプチドよりも有意に 高值(スレオニン, セリン, プロリン, バリン, メチオニン, イソロイシン, ロイシン, チロシン, ヒスチジン,リジン，アルギニン； $\mathrm{p}<0.01)$ を 示した.

\section{B. 実験 2}

B-1. Control 群と Training 群の体重 両群における体重の経時的な変動を図 6 に示し た.この両群は, 経過観察期間である10週齢から 11週齢では両群間に体重の差はみられず，同様の 増加を示していた。しかし, 実験を開始した11週 齢以降になると, Control 群では体重が一定の増 加を示すのに対して, Training 群では強制運動

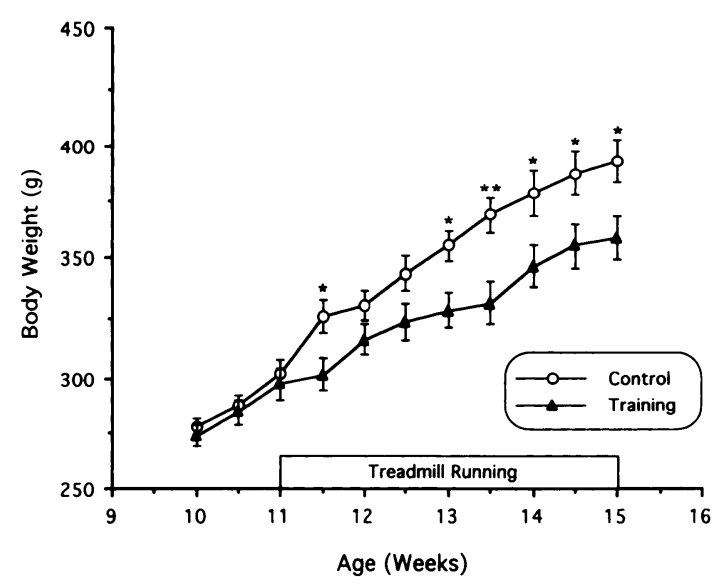

Fig. 6. Change of body weight in the two groups. Each symbol and vertical bar represents mean value and standard error of each group, respectively.

* ; significant difference between Control group and Training group, $\mathrm{p}<0.05$.

$* *$; significant difference between Control group and Training group, $\mathrm{p}<0.01$.
が始まった直後から体重の増加に抑制がみられ， 運動開始と同時に体重が減少し有意差 $(\mathrm{p}<0.05)$ がみられていた。しかし，その後，この有意差は 一時的に消失をみるものの次第に Control 群との 差が顕著となり，13週齢以降 $(\mathrm{p}<0.05)$ に再び有 意差が認められ，飼育条件期間終了までその有意 差が拡大した $(\mathrm{p}<0.05$ および $\mathrm{p}<0.01)$.

B-2. Control 群と Training 群の飭の損取 量

Control 群と Training 群における飭の摂取量の 経時的変化を図 7 に示した。10週齢から11週齢の 経過観繁期間では餌の摂取量に両群の差はみられ なかったが，トレッドミル走行を開始した11週齢 から Training 群では Control 群と比較して低值 を示し，15週齢まで Control 群を上回ることはな かった。

B-3. Control 群と Training 群の臟器重量 臟器重量の成績を表 1 に示した. Control 群お よび Training 群を比較したところ, Training 群 がControl 群より有意に高值を示していたもの は, 心臓 $(\mathrm{p}<0.05)$, 腎臓 $(\mathrm{p}<0.05)$ および副腎 $(\mathrm{p}<0.01)$ であり, 逆に Control 群が Training 群

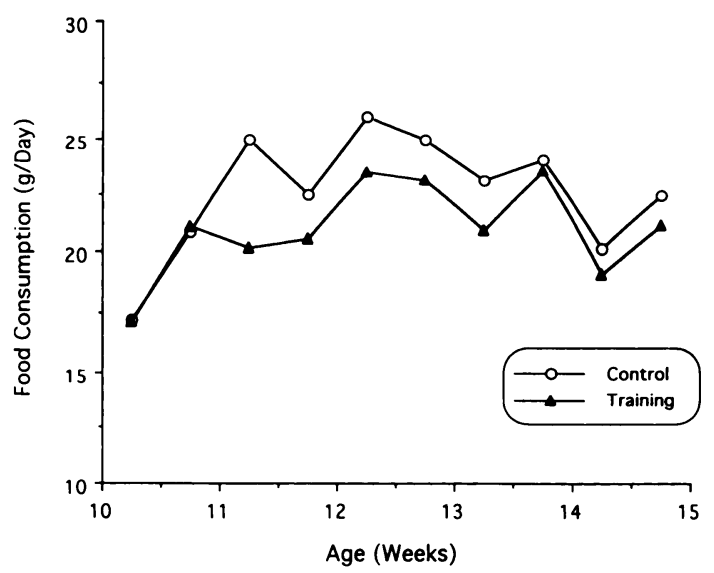

Fig. 7. Change of food consumption in the two groups.

Each symbol and represents mean value of food consmptions in each group. No statistical analysis was carried out. 
Table 1. Body weight and organ weights.

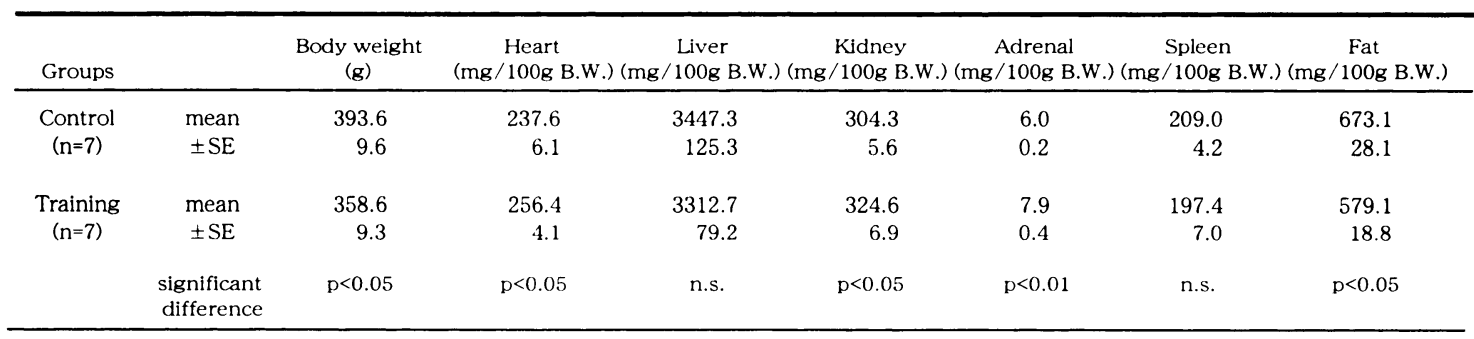

n. s. ; not siginificant

Values are means and standard error.

より有意に高值を示していたものは脂肪 $(\mathrm{p}<$ 0.05)のみであった。

B-4. Control 群と Training 群の吸光度増 加面積

腸管潅流装置を用いて行った紫外部吸光の測定 結果から吸光度増加面積を求めた成績を図 8 に示 した。その結果, Training 群の漿膜側液中にみ られた $278 \mathrm{~nm}$ の吸光度面積 $\left(1.7 \pm 0.4 \mathrm{~cm}^{2}\right)$ は, Control 群の面積 $\left(2.0 \pm 0.4 \mathrm{~cm}^{2}\right)$ と比較して低值 を示したが，その差は有意なものではなかった。

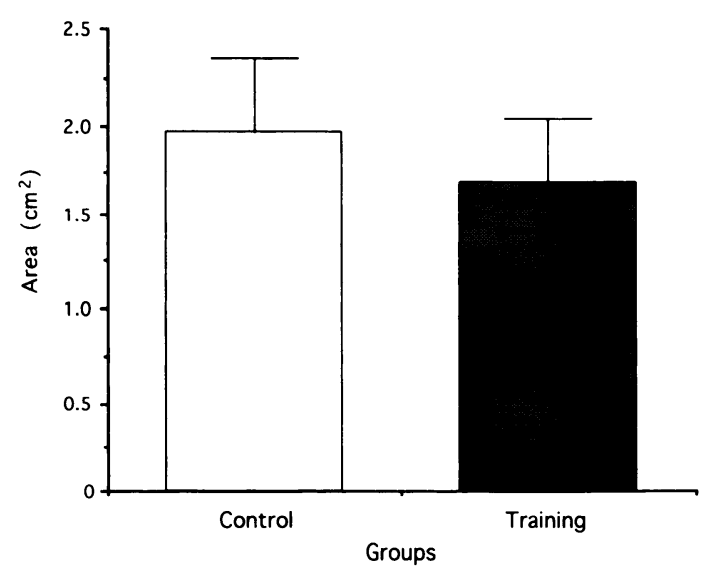

Fig. 8. Penetration of collagen peptide through the intestinal membrane.

Each column and vertical bar represents mean value and standard error of each group. respectively. There was no statistically siginificant difference among groups.
B-5. Control 群と Training 群のアミノ酸 分析

潅流が終了した直後の漿膜側液中のアミノ酸分 析の成績を図 9 に示した。その結果, 両群ともに アラニン (Training 群 ; $235.5 \pm 14.0 \mathrm{n} \mathrm{mol} / \mathrm{ml}$, Control 群 ; $205.7 \pm 26.8 \mathrm{nmol} / \mathrm{ml})$ が最も高值を 示して抢り，次いでグリシン (Training 群 ; 208.2 $\pm 18.5 \mathrm{nmol} / \mathrm{ml}$, Control群 ; $178.1 \pm 24.7 \mathrm{nmol} /$ $\mathrm{ml})$, プロリン (Training 群; $92.9 \pm 6.9 \mathrm{nmol} / \mathrm{ml}$, Control 群; $77.4 \pm 9.5 \mathrm{nmol} / \mathrm{ml})$ の順に高值を示 していた。また, 両群の比較では, いくつかの項

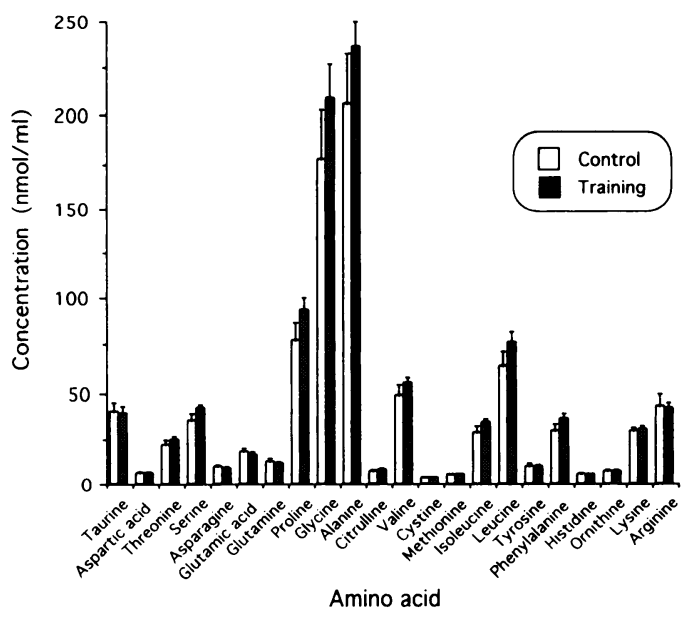

Fig. 9. Quantitative analysis of amino acid composition of the penetrated fluid through the intestinal membrane.

Each column and vertical bar represents mean value and standard error of each group, respec. tively. There was no statistically siginificant difference among groups. 
目で Training 群が高值を示していたものの, 検 出されたアミノ酸すべての項目において, Control 群と Training 群との間に有意な差が認めら れなかった。

\section{N. 考}

察

近年, スポーツ選手達が骨格筋量の増量や, そ れに伴うパフォーマンスの向上を目的として蛋白 質性食品を摂取する傾向が見受けられるようにな り, 競技特性に応じて数多くの蛋白性食品が利用 されてきている，さらに，最近注目されてきてい るコラーゲンペプチドは, 靫帯や腱などに多く含 まれているため，スポーツ現場においてサプリメ ントとしての摂取が注目されてくるところであ る。一般に, 蛋白質はアミノ酸まで分解されて吸 収されるといわれている。しかし，前述のように， 近年，ある程度の蛋白体がその構造や機能を残し たまま腸管壁を通過することも報告されてきてお り，その機序として飲作用やパーメーションの機 構が考えられている。また，蛋白質を経口的に椇 取したからといって，そのすべてが体内に取り入 れられるというものでない，そこで本実験では， 蛋白質の種類や性状によってどの程度の蛋白体 が，腸管壁を通過し吸収されるか否かについての 検討を試みたのである．本実験では，まず実験 1 としてホエイペプチドと大豆ペプチドを用い，ラ ット腸管壁通過現象の違いについて比較検討を行 った。また，実験 2 ではラットに強制運動を行わ せ，コラーゲンペプチドの腸管壁通過現象を測定 し，強制運動による影響がみられるか否かの実験 を試みた。

まず，実験1では，あらかじめホエイペプチド および大豆ぺプチドの紫外部吸光度曲線について 検討した。その成績から，両者ともに $278 \mathrm{~nm} に$ 特異的な吸光度を有し，しかも，ペプチド濃度に 依存して吸光度の増加がみられた。そこで，潅流 装置に接続した僠転腸管の粘膜側に両ぺプチドを それぞれ添加してから30分間に増加する漿膜側液 中の $278 \mathrm{~nm}$ の紫外部吸光度増加面積について検 討を行った。この両者の成績を比較すると，両ぺ プチドがともに腸管壁を通過し，また，ホエイペ
プチドの方が大豆ペプチドに比して図 4 のように 有意に高值を示していた。

次に, 60分間の潅流が終了した直後の漿膜側液 を採取しアミノ酸分析を行ったところ，両ペプチ ドを添加した場合には，何も添加しなかった場合 の Controlに比して, 殆どのアミノ酸項目で図 5 にみられるように有意に高值を示した。このこと は，アミノ酸組成からみても明らかなように両ぺ プチドがともに腸管壁を通過したことを示してい る。また，ホエイペプチドと大豆ペプチドを比較 すると殆どのアミノ酸について，ホエイペプチド が大豆ペプチドよりも有意に，あるいは高值を示 す傾向にあった。したがって，この両ぺプチド構 成アミノ酸組成を各々比較した場合でも，ホエイ ペプチドの方が大豆ペプチドよりも腸管壁をより 通過しており, この成績は紫外部吸光度面積の变 動と同様の成績であった。

本実験で使用したホエイペプチドおよび大豆ぺ プチドは，ともに酵素処理によってオリゴペプチ ドまで分解されている，生体内における蛋白質の 吸収については，アミノ酸の他にジペプチドある いはトリペプチドがそのままの形で膜輸送される ペプチド輸送系の存在が明らかにされており ${ }^{11)}$, 蛋白質やアミノ酸よりも吸収が速く12１6），アミ ノ酸がバランスよく吸収される ${ }^{12,17.18)}$ 。また, アミノ酸輸送系では側鎖の長さと分子量とが輸送 の親和性によく相関するといわれ，必須アミノ酸 の優先性が認められている，中埜たち ${ }^{19)}$ は，消 化酵素を用いた人工消化試験およびラットを用い た in-vivoの実験で，腸管内におけるぺプチドの 消化性と腸管から血中へのアミノ酸移行速度か ら，ホエイ蛋白質とホエイペプチドについて検討 を行っている，その結果，ホエイペプチドは小腸 への移行速度が速く吸収性にも優れていることを 確認している。また，全たち ${ }^{20,21)}$ はペプチド鎖 長の異なった2種類の大豆加水分解産物をラット の小腸で潅流し、ペプチドの鎖長が吸収に与える 影響について検討し，ラット小腸反転腸管の潅流 実験としては小ペプチドの方がよく吸収されたと している，さらに，Glinbleたち22,23)も小腸で の吸収について鎖長の異なるぺプチドを用いて検 
討し, 低分子ペプチドが高分子ペプチドよりも吸 収の速いことを報告している。したがって，ホ工 イペプチドおよび大豆ペプチドはともに消化吸収 性に優れており 19.24)，特に，本実験で用いたホ エイペプチドおよび大豆ペプチドは，ともに低分 子化された蛋白体のオリゴペプチドであることか ら, 腸管壁の通過が羿められたものと思われる。 また，本実験成績からは，ホエイペプチドが大豆 ペプチドよりも通過しやすいいことが明らかにな った。これら両ぺプチドを添加した各々の漿膜側 液中のアミノ酸分析結果についてみると, 多く通 過していたアミノ酸は必須アミノ酸であった。仮 に,腸管粘膜をよく通過していた必須アミノ酸が, その膜輸送体によって選択的に通過しやすくなっ ていたとするならば，必須アミノ酸を多く含むホ エイペプチドの方が大豆ペプチドよりも，よく腸 管壁を通過する可能性も考えられる。したがって, ホエイペプチドと大豆ペプチドの腸管壁通過量の 違いは，一部は分子量の違いによって説明できる が，他の要素もこの通過に影響している可能性が 考えられる。

次に実験 2 について検討した. Training 群に おける体重の増加は, 強制運動を開始した直後に 抑制がみられ，週齢を重ねるに従い図6にみられ るようにControl 群と Training 群の間に顕著な 差がみられていた。本実験で Training 群に負荷 した $35 \mathrm{~m} / \mathrm{min}$ のトレッドミル走行は, ラットに おける最大酸素摂取量 $\left(\dot{\mathrm{VO}}_{2} \mathrm{max}\right)$ の約 $80 \%$ に相当 することが報告されており 25.26)，11週齢から行 わせる運動としては高強度運動であったものと思 われる。一方, 飭の撕取量をみると, Training 群では Control 群に比してトレッドミル走行を開 始した11週齢から減少し，15週齢まで Control 群 より低值を維持しており(図 7 ), 体重と慨の摂取 量にみられた本実験の成績は, 既報の成績 ${ }^{27)}$ と 類似していた. Training 群でみられた体重の増 加の抑制は, 少なくともその要因の 1 つとして運 動による消費エネルギーの増大よりも摃取エネル ギーの減少であることが考えられる。すなわち， 強制運動による交感神経緊張状態が消化管の運動 や消化・吸収を抑制し，慢性的に自律神経などに
影響を与えていた可能性 ${ }^{28)}$ や, 水分代謝の変動 から消化機能に影響を与え ${ }^{29)}$, 食欲不振に宿つ ていた可能性も考えられる。さらに, 表 1 に示し た体重 $100 \mathrm{~g}$ に対する臟器重量についてみると,

Training 群は Control 群と比較して心臓, 腎臓お よび副監が有意に高値を示していた。また, 副腎 の重量はストレスをみる指標としてょく用いられ ているが30), Training 群の副腎重量が Control 群よりも高値を示していたことからも, 強制運動 がラットにとって相当のストレッサーであったこ とが推察される゙で.

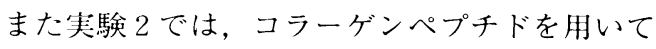
強制運動を行わせたラットの翻転腸管における腸 管壁通過現象について検討した。コラーゲンは, 33種類以上の遺伝子からなる蛋白質のスーパーフ アミリーであり，一般にコラーゲンとしてはポリ ペプチド鎖の 3 本が会合し, らせん構造を形成し ている ${ }^{31)}$.コラーゲンは, その分子の種類に対 忍して I 型， II 型，血型などと呼ばれているが， 皮䖉, 骨, 腱などの主要コラーゲンはI 型であり, また, 軟骨では II 型が主要となっている32). 近年, コラーゲンペプチドを含んだ食品が盛んに開発さ れてきているが，コラーゲンペプチドの経口摂取 により期待される効果としては, 皮膚コラーゲン の代謝促進作用に伴う皮膚の正常化をはじめ, 骨 のコラーゲン構造を強固にし, 骨強度を高める効 果や腱を丈夫にする働きなどが期待 ${ }^{32)}$ されてお り，スポーツ選手の掑取食物として今後注目され るであろうことが考えられる。

なお，私たちは本実験で使用したコラーゲンペ プチドが $278 \mathrm{~nm}$ に特異的な紫外部吸光を有し, この量的な検量曲線を作成することによって微量 定量が可能であることを報告している10).そこ で，本実験でも $278 \mathrm{~nm}$ の波長でコラーゲンペプ チドの腸管壁通過現象を測定した。その結果, 困 8のようにControl 群および Training 群ともに 漿膜側液中の吸光度に増加がみられ, 紫外部吸光 を有する蛋白体としてのコラーゲンペプチドが腸 管粘膜を通過していた。また，両群の吸光度面積 を比較したところ, Training 群は Control 群より 低佃を示していたものの有意の差はみられなかっ 
た。そこで，次にコラーゲンペプチドが通過した と考えられる漿膜側液のアミノ酸構成について検 討した。その結果, 図 9 に示すようにControl 群 および Training 群ともにアラニンが最も高值を 示しており，次いでグリシン，プロリンの順に高 值であった，本来コラーゲンペプチドは，グリシ ンを最も多く含んでいるが，本成績ではアラニン が最も高值を示した。理由の 1 つとして, 実験 1のアミノ酸分析の結果からも明らかなように, 粘膜側に何も添加しなかった Control についても アラニンが高值を示しており，グリシンとの差は 顕著であった，仮に，実験 1 の Control における アラニンとグリシンの值を，実験 2 におけるそれ らの值から差し引くと, グリシンが最も多くなる ことが予想される。したがって，残留血液中血漿 蛋白および腸粘膜からの可溶性組織蛋白の影響に より，実験 2 ではアラニンが見かけ上，最も高值 を示したものと考えられる。一方，Control 群と Training 群とを比較したところ，検出されたア ミノ酸項目のすべてについて両群の間に有意の差 は認められなかった。

今回のコラーゲンペプチドの腸管壁通過現象か らみた成績は, 紫外部吸光を有する物質が腸管壁 を通過することを立証しているものの，この成績 のみから投与したコラーゲンペプチドがその構造 や機能を維持したまま腸管壁を通過したか否かに ついては明らかにはならなかった。さらに，本実 験では強制運動の期間を 4 週間と限定しており， その影響を検討するには短期間であったかもしれ ない. 今後, さらに運動の期間を延長し, コラー ゲンペプチドの吸収について検討していく予定で ある。また，本実験は腸管壁通過現象を測定した in-vitroの実験であり，生体内でのさらなる検討 が必要であるとともに，スポーツ現場におけるコ ラーゲンペプチドの利用の本質についてもさらに 検討していく必要があるだろう。

\section{V. 要 約}

本実験では, 実験 1 としてホエイペプチドと大 豆ペプチドのラット翻転腸管による腸管壁通過現 象の比較検討を行った。また，実験2として強制
運動を行わせたラットを用い，コラーゲンペプチ ドの腸管壁通過現象について検討を行った。

すなわち，実験 1 では，ラットの翻転腸管の粘 膜側にホエイペプチド拉よび大豆ぺプチドを添加 した場合, 紫外部吸光度増加面積およびアミノ酸 分析の成績から，両者ともに腸管壁を通過したこ とが認められた。なお，この両ペプチドの腸管壁 通過を比較した場合，ホエイペプチドが大豆ペプ チドより有意に高值を示し，ホエイペプチドの方 が大豆ペプチドよりも腸管壁を通過しやすいこと を示していた。

次に, 実験 2 の強制運動を行ったラットでは, 体重の増加に抑制がみられ, 臟器重量からも運動 による生体への影響が認められた。また，Training 群とControl 群における翻転腸管の粘膜側に コラーゲンペプチドを添加した場合には, 両群と もにコラーゲンペプチドが腸管壁を通過してい た。しかし，この両群のコラーゲンペプチドの腸 管壁通過現象には有意の差は認められなかった。

したがって，コラーゲンペプチドが腸管壁を通過 することは明確であったが，強制運動による腸管 壁通過現象には著明な影響はみられなかった。

\section{謝 辞}

稿を終えるにあたり，本研究に終始ご協力下さいま した明治製菓株式会社ザバス スポーツ\&ニュートリ ション・ラボの杉浦克己所長および同社生物科学研究 所機能研究センターの太田篤胤主任研究員に厚く御礼 申し上けげます。また，貴重なご助言を頂いた日本体育 大学の中里浩一講師に謝意を表します.

なお，本研究の一部は平成 12 年度財団法人水野又 ポーツ振興会研究助成金および日本学術振興会平成 12 年度および13年度科学研究費補助金 (奨励研究 $(A))$ 課 題番号12780041によった。

(受理日 平成14年12月 6 日)

\section{参考文 献}

1) 中野昭一, 佐藤恒久, 小原 㑆, 村松成一, In sulin および Proteolytic Enzyme の腸管通過，ホル モンと臨床, (1967), 15, 411-417.

2）中野昭一，蛋白質・活性ポリペプチッドの腸管吸 収，日本医事新報，(1977），2778，132-133。

3）太田富貴雄, 運動とたんぱく質椇取, 臨床栄養, (1992), 80, 495-502. 
4) Burke. D. G., Chilibeck, P. D., Davison, K. S., Candow, D. G., Farthing, J., Smith-Palmer, T. The effect of whey protein supplementation with and without creatine monohydrate combined with resistance training on lean tissue mass and muscle strength. Int. J. Sport. Nutr. Exerc. Metab., (2001), 11, 349364 .

5）村松成司, 山崎俊輔, 服部洋兒, 服部祐兒, 柔道 選手の連動作業能に及ほす大音ぺプチド長期椇取 の効果, 千葉大学研究, (1994), 18, 41-48.

Muramatsu, S., Yamazaki, S., Hattori, Y., Hattori, Y. Effect of soy-peptide intake for long term on exer. cise performances of Judo athletes. Chiba Journal of Physical Education, (1994), 18, 41-48 (in Japanese).

6) 三浦孝仁, 竹中省子, 奥野真理, 小原信幸, パワー リフティング選手の運動作業能に及ほす大立ぺプ チド \& SIP 長期拱取効果, 岡山大学教育学部研究 集録, (1995), 100, 139-150.

Miura, K., Takenaka, S., Okuno, M., Kohara, N. Effect of soy-bean peptide and soy-bean isolated protein intake over 6 months on work capacity of powerlifters. Bulletin of School of Education, Okayama University, (1995), 100, 139-150 (in Japanese).

7) Di Pasquale, M. Amino acids and proteins for the athlete- the anabolic edge, Protein foods vs. protein and amino acid supplements, Chap. 5, CRC Press LLC, Florida, (1997), 89-98.

8）福井健介, スポーツフードへの大豆たん白質・ベ プチドの利用, 食品と開発, (2000), 35(2), 54-56.

9）小出 輝, 林 利彦編. 細胞外マトリックス一基 礎と臨床一, 初版, 細胞外マトリックスの主要繊 維成分, 爱智出版, 東京, (2000), 2-40。

10）谷浩充, 鈴川一宏. 清田 寞, 大和 黃, 中野昭一, ラット旙転腸管における腸管吸收能について, 日本 体育大学研究所雑誌, (2000), 25, 157-164.

Tani, H. Suzukawa, K., Kiyota, H., Yamato, M., Nakano, S. Study on intestinal absorption in everted intestine. J. of Res. Inst. of Physical Education, Nip pon Sport Science University, (2000), 25, 157-164 (in Japanese).

11) Matthews, D. M. Intestinal absorption of peptides. Physiol. Rev., (1975), 55, 537-608.

12）山本 茂，蛋白質，ペプチドおよびアミノ酸の体 内利用に関する研究, 日本栄養·食糧学会誌, (1986), 39, 81-88.

Yamamoto, S. Utilization of protein, peptides and amino acids in whole body. J. Jpn. Soc. Nutr. Food Sci., (1986), 39, 81-88 (in Japanese).

13) Adibi, S. and Phillips, E. Evidence for greater absorption of amino acids from peptide than from free form in human intestine. Clin. Res., (1968), 16. 446.

14) Craft, I. L., Geddes, D., Hyde. C. W., Wise, I. J., Matthews. D. M. Absorption and malabsorption of glycine and glycine peptides in man. Gut, (1968), 9.
$425-437$

15) Silk, D. B. A., Marrs, T. C., Addison, J. M., Burston, D., Clark, M. L., Matthews, D. M. Absorption of amino acids from an amino acid mixture simulating ca. sein and a tryptic hydrolysate of casein in man. Clin. Sci. Mol. Med., (1973), 45, 715-719.

16) Hara, H., Funabiki, R., Iwata, M., Yamazaki, K. Portal absorption of small peptides in rats under unrestrained conditions. J. Nutr., (1984), 114, 1122-1129.

17) Steinhardt, H. J., Adibi, S. A. Kinetics and characteristics of absorption from an equimolar mixture of 12 glycyl-dipeptides in human jejunum. Gastroent. 90, 577-582.

18）星 猛，小腸の消化吸収機能に見る進化の妙，消 化と吸収, (1987)，20，19-26.

19）中埜拓，島谷雅治，村上雄二，佐藤則文，井戸 用 正, 乳清夕ンパク質酵素分解物の消化吸収性, 日本栄養·食糧学会誌, (1994)，47，195-201. Nakano, T., Shimatani, M., Murakami, Y., Sato, N., Idota. T. Digestibility and absorption of enzymati. cally hydrolyzed whey protein. J. Jpn. Soc. Nutr. Food Sci., (1994), 47, 195-201 (in Japanese).

20）全 活, 佐々木雅也, 辻川知之, 藤山佳秀, 馬場 忠雄，斗均ぺプチド鎖長の異なる2種の大豆ペプチ ドの腸管吸収の検討，消化と吸収，(1996)，19，2025.

Chun, H., Sasaki, M., Tsujikawa, T., Fujiyama, Y., Bamba, T. Absorption of two types of soybean pep. tides from everted sacs of rat small intestine. Dig. Absorpt. (Tokyo), (1996), 19, 20-25 (in Japanese).

21) Chun, H., Sasaki, M., Fujiyama, Y., Bamba, T. J. Clin. Biochem. Small peptide of soybean hydrolysate is absorbed more rapidly than large peptide in the perfused rat small intestine. Nutr., (1999), 26, 183191

22) Grimble, G. K., Keohane, P. P.. Higgins, B. E., Kaminski, M. V., Silk, D. B. A. Effect of peptide chain length on absorption of two lactalbumin hyd. rolysates in the normal human jejunum. Clin. Sci., (1986), 71, 65-69.

23) Grimble, G. K., Rees, R. G., Keohane. P. P., Cart. wright. T., Desreumaux, M., Silk, D. B. A. Effect of peptide chain length on absorption of egg protein hydrolysates in the normal human jejunum. Gas. troent., (1987), 92, 136-142.

24）青山敏明，福井健介，山本孝史，ラットに強制投 与された窒素源の違いが胃内通過時間に及ぼす影 響，甘本栄養・食糧学会誌，（1996），49，46-51。 Aoyama, T., Fukui, K., Yamamoto, T. Effect of various forms of force-fed nitrogen sources on gas. tric transit time in rats. J. Jpn. Soc. Nutr. Food Sci., (1996), 47, 46-51 (in Japanese).

25) Brooks, G. A., \& White, T. P., Determination of metabolic and heart rate response of rats to tread. mill exercise. J. Appl. Physiol.. (1978), 45, 10091015 
26）跡見順子，八田秀雄，山本順子，山田 茂，浅見 俊雄, 黒田善雄, ラットのトレッドミル走におけ るスピード- $\mathrm{VO}_{2}$ 関係および $\mathrm{VO}_{2} \mathrm{max}$ の測定方法 の検討, 東京大学教養学部体育研究室体育学紀要, (1985), 19, 69-73.

Atomi, Y., Hatta, H., Yamamoto, Y., Yamada, S., Asami, T., Kuroda, Y. Determination of Speed- $\mathrm{VO}_{2}$ relationship $\mathrm{VO}_{2}$ max of rats during treadmill exer. cise. The Proceedings of the Department of Sports Sciences, College of Arts and Sciences, University of Tokyo, (1985), 19, 69-73 (in Japanese).

27）鈴川一宏, 熊江 隆, 荒川はつ子, 石崎香理, 伊 藤 孝, 内山尛雄, 成熟ラットにおける強制運動 と睡眠妨害の組み合わせが気管支肺胞洗浄液中細 胞に及ほす影響, 体力科学, (1997)，46，389-398. Suzukawa, K., Kumae, T., Arakawa, H., Ishizaki, K., Ito, T., Uchiyama, I. The combined effects of stre- nuous exercise and sleep disturbance on cell in bronchoalveolar lavage fluids in mature rats. Jpn. J. phys. Fitness sports med., (1996), 46, 389-398 (in Japanese).

28）井川幸雄, 運動と消化・吸収および消化器症状, 臨 床スポーツ医学, (1989), 6, 1189-1192.

29）石河利寛. 健康 - 体力のための運動生理学, 初版, 消化吸収と運動, 杏林書院, 東京, (2000), 173-198.

30) 鈴川一宏, 熊江 隆, 荒川はつ子, 内山瞃雄, 伊 藤 孝, 成熟後ラットへの運動負荷と時差が体重 および蔵器重量に及ぼす影響, 体力・栄養免疫学雑 誌, (1993)，46，26-30.

31) 小出 輝, 林 利彦 編. 細胞外マトリックスー 基礎と臨床一，コラーゲンスーパーファミリータ ンパク質, 初版, 愛智出版, 東京, (2000), 94-138.

32) 本田真樹, コラーゲンペプチドの機能性研究, 食 品と開発，(1998)，33(4), 46-50. 